\title{
Effects of Malachite Green on the Microbiomes of Milkfish Culture Ponds
}

\author{
Chu-Wen Yang, Yi-Tang Chang $\mathbb{B}$, Chi-Yen Hsieh and Bea-Ven Chang *
}

check for updates

Citation: Yang, C.-W.; Chang, Y.-T.; Hsieh, C.-Y.; Chang, B.-V. Effects of Malachite Green on the Microbiomes of Milkfish Culture Ponds. Water 2021, 13, 411. https://doi.org/ 10.3390/w13040411

Received: 23 December 2020

Accepted: 29 January 2021

Published: 4 February 2021

Publisher's Note: MDPI stays neutral with regard to jurisdictional claims in published maps and institutional affiliations.

Copyright: (C) 2021 by the authors. Licensee MDPI, Basel, Switzerland. This article is an open access article distributed under the terms and conditions of the Creative Commons Attribution (CC BY) license (https:// creativecommons.org/licenses/by/ $4.0 /)$.
Department of Microbiology, Soochow University, Taipei City 11102, Taiwan; ycw6861@scu.edu.tw (C.-W.Y.); ytchang@scu.edu.tw (Y.-T.C.); seraphin25285026@gmail.com (C.-Y.H.)

* Correspondence: bvchang@scu.edu.tw

\begin{abstract}
Intensive fish farming through aquaculture is vulnerable to infectious diseases that can increase fish mortality and damage the productivity of aquaculture farms. To prevent infectious diseases, malachite green (MG) has been applied as a veterinary drug for various microbial infections in aquaculture settings worldwide. However, little is known regarding the consequences of MG and MG-degrading bacteria (MGDB) on microbial communities in milkfish culture ponds (MCPs). In this study, small MCPs were used as a model system to determine the effects of MG on the microbial communities in MCPs. The addition of MG led to cyanobacterial blooms in the small MCP. The addition of MGDB could not completely reverse the effects of MG on microbial communities. Cyanobacterial blooms were not prevented. Microbial communities analyzed by next generation sequencing revealed that cyanobacterial blooms may be due to increase of nitrogen cycle (including nitrogen fixation, nitrate reduction and anammox) associated microbial communities, which raised the levels of ammonium in the water of the small MCP. The communities of anoxygenic phototrophic bacteria (beneficial for aquaculture and aquatic ecosystems) decreased after the addition of MG. The results of this investigation provide valuable insights into the effects of MG in aquaculture and the difficulties of bioremediation for aquatic environments polluted by MG.
\end{abstract}

Keywords: malachite green; microbiome; cyanobacterial blooms; nitrogen cycle

\section{Introduction}

The proportion of world aquaculture has reached $46 \%$ of global fish production in 2018 . Inland aquaculture produced the most farmed fish (62.5\% of the world total) [1]. For example, milkfish (Chanos chanos) is typically cultured in coastal areas in Taiwan, Indonesia, Philippines and India [2]. As a euryhaline fish, milkfish are cultured in a wide range of salinities [3]. Intensive fish farming through aquaculture is vulnerable to infectious diseases that can increase fish mortality and reduce the productivity of aquaculture farms $[4,5]$. Malachite green (MG, [4-[[4-(dimethylamino)phenyl]-phenylmethylidene]cyclohexa-2,5dien-1-ylidene]-dimethylazanium;chloride) has been largely used to prevent outgrowth of fungi on fish and fish eggs, both as a post-infection therapy and prophylaxis [6-8]. MG has been used effectively to control protozoans [9-12]. MG has also been used as a parasiticide [13-15]. The LC50 values of MG on various fishes have been estimated [16]. However, it has been suggested that toxicity of MG on different species of fish are difficult to compare because LC50 values are affected by various factors such as temperature, $\mathrm{pH}$ and many other chemical compositions of aquaculture water. The use of MG has been banned in European Union and not approved by US Food and Drug Administration. However, MG is still being used in many parts of the world due to its low cost and effectiveness in many infectious diseases [17]. MG and LMG are important test items for food safety [18-20].

Concerns related to MG are based on the health risks of the residues of $\mathrm{MG}$ and its derivative leucomalachite green (LMG, 4-[[4-(dimethylamino) phenyl]-phenylmethyl]-N, $\mathrm{N}$-dimethylaniline) are frequently identified in aquaculture products [17,21-25]. MG and LMG have been shown to induce the formation of reactive oxygen species (ROS) and cause 
DNA damage and considered as carcinogens in mice [26]. The incidence of hepatocellular adenomas and carcinomas increased in rats after treatments of MG/LMG [27]. The risk of thyroid and mammary cancers also increased in female rats by MG/LMG [28].

Total phosphorus and nitrogen sources nitrogen transformation and the bioavailability of different nitrogen forms are major factors lead to eutrophication [29,30]. Eutrophication may induce cyanobacterial blooms (and may be toxic sometimes) in freshwater and marine environments, which destroy water quality for aquatic ecosystem functions. Four strategies were proposed for the prevention and control for cyanobacterial blooms [31]. First, using nutrient management to reduce external nutrient inputs to tackle the root of the problem. Second, addition of phosphate- binding clays and capping of sediments remove nutrients from the water. Third, chemical controls which are used for emergencies. Fourth, biological controls, such as manipulation of microbial communities in aquatic environments to prevent cyanobacterial growth $[32,33]$.

For aquaculture, little is known regarding the interactions between antimicrobials, water quality and microbial communities in brackish fish culture ponds. Bacteria that can decompose organic pollutants in the culture water can be used as beneficial bacteria for aquaculture [34-36]. Study of Chang et al. (2019) demonstrated that the addition of sulfamethoxazole (SMX) decreased the abundance of ammonia-oxidizing bacteria (AOB), nitrite-oxidizing bacteria (NOB) and photosynthetic bacteria in milkfish culture ponds. Increased levels of ammonium and total phosphorus in the milkfish culture pond water led to algal and cyanobacterial blooms. The addition of the SMX-degrading bacteria effectively degraded SMX in milkfish culture pond water. The abundances of AOB, NOB and photosynthetic bacteria were restored, and algal and cyanobacterial blooms were prevented [37]. Several MG-degrading bacteria (MGDB) have been identified and investigated [38-41]. Two MGDB strains M10 (Tenacibaculum sp.) and M12 (Enterobacter sp.) were isolated by Yang et al. (2019) from sediments of farm-scale milkfish culture ponds (MCPs) [42]. Intermediate degradation products of MG in MCP with the addition of MGDB strains M10 and M12 have been identified. However, little is known regarding the consequences of MG and MGDB on nitrogen cycle and microbial communities in MCPs. In this study, small MCPs were used as a model system to assess the effects of MG and MGDB on the chemical composition of water and microbial communities in the water and sediment of MCPs.

\section{Materials and Methods}

\subsection{Chemicals}

Chemicals used in this study, including MG (99.0\% purity), monopotassium phosphate $\left(\mathrm{KH}_{2} \mathrm{PO}_{4}\right)$, disodium phosphate dodecahydrate $\left(\mathrm{Na}_{2} \mathrm{HPO}_{4} \cdot 12 \mathrm{H}_{2} \mathrm{O}\right)$, ammonium chloride $\left(\mathrm{NH}_{4} \mathrm{Cl}\right)$, calcium chloride $\left(\mathrm{CaCl}_{2}\right)$, magnesium sulphate-7hydrate $\left(\mathrm{MgSO}_{4} \cdot 7 \mathrm{H}_{2} \mathrm{O}\right)$, ferric chloride hexahydrate $\left(\mathrm{FeCl}_{3} \cdot 6 \mathrm{H}_{2} \mathrm{O}\right)$, and formic acid, were purchased from SigmaAldrich (St. Louis, MO, USA). Marine broth was purchased from BD Difco ${ }^{\mathrm{TM}}$ (Franklin Lakes, NJ, USA). Solvents (acetonitrile and methanol) were purchased from Mallinckrodt, Inc. (McDonnell Boulevard, St Louis, MO, USA). The quality of all chemicals is analytical grade.

\subsection{Experimental Settings of Small MCPs}

The settings and timeline of the small MCP experiments are shown in Figure 1. Each small MCP is consisted of $700 \mathrm{~L}$ of farm-scale MCP water and $100 \mathrm{~kg}$ of farm-scale MCP sediment in a $1000 \mathrm{~L}$ tank. Water and sediment were taken from a farm-scale milkfish pond at the Mariculture Research Center, Fisheries Research Institute, Tainan. 1.4 g MG was dissolved in $500 \mathrm{~mL}$ milkfish pond water $(2.8 \mathrm{~g} / \mathrm{L})$ and then added to the $2 \mathrm{nd}$ and 3rd small milkfish pond. MGDB cultures of $250 \mathrm{~mL}\left(10^{6} \mathrm{CFU}\right)$ M10 (Tenacibaculum sp.) and $250 \mathrm{~mL}\left(10^{6} \mathrm{CFU}\right) \mathrm{M} 12$ (Enterobacter sp.) were centrifuged $5000 \mathrm{~g}$ for $5 \mathrm{~min}$. The supernatants were discarded and each pellet was resuspended by $250 \mathrm{~mL}$ milkfish pond water. The bacterial suspensions were mixed and added to the 3rd small milkfish pond. The experimental period was 9 weeks. The first week (week 0 , before milkfish addition) 
was the period to wait for the sediment to precipitate and the water became clear after the tanks were set. Twenty milkfishes that were 18-20 cm in length were added to each pond on the last day of week 0 . Samples of water and sediment were collected as indicated in Figure 1.

\section{Settings of small milkfish ponds}
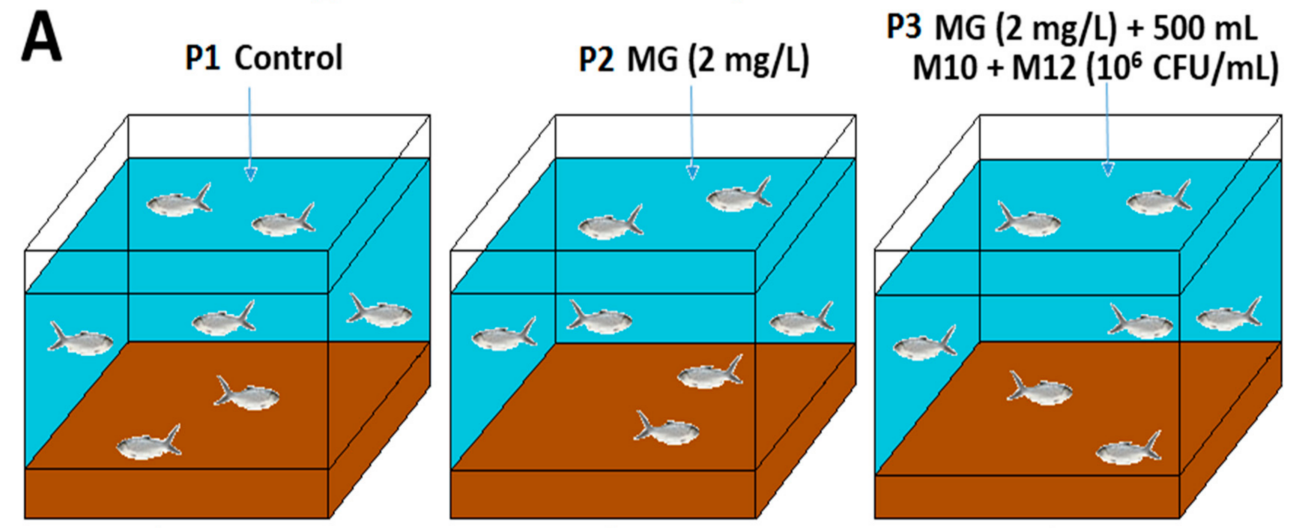

$700 \mathrm{~L}$ milkfish pond water $+100 \mathrm{Kg}$ milkfish pond sediment

B



Figure 1. (A) Experimental setting of small milkfish ponds and timeline of sampling. (B) W0: the week before the addition of milkfish. W1-W8: the first to the 8th week after the start of the experiment. Red arrows indicate the times of water and sediment sampling. NGS indicates that the microbial communities in the samples were analyzed using next generation sequencing.

\subsection{Analysis of $M G$}

MG was extracted twice from water and the sediment suspension samples with acetonitrile. Extracts were analyzed using an Agilent 1260 HPLC system equipped with a $4.6 \times 100-\mathrm{mm}$ column (Poroshell 120 EC-C18, Agilent, Santa Clara, CA, USA) with a photodiode array detector monitoring at 615, 259 and $366 \mathrm{~nm}$ for MG. The mobile phase was acetonitrile and water (containing $0.1 \%$ formic acid) at a ratio of $30 \%: 70 \%$ for three $\mathrm{min}$, followed by a change ratio of $10 \%: 90 \%$ for seven $\mathrm{min}$. The flow rate was $1 \mathrm{~mL} / \mathrm{min}$. The average recovery rate MG was $98.2 \pm 4.8 \%$, and the detection limit was $0.5 \mathrm{mg} / \mathrm{L}$.

\subsection{Analysis of Water Quality in Small Milkfish Ponds}

Water samples (100 $\mathrm{mL}$ for each sample) from the small MCPs were filtered by a $1.20 \mu \mathrm{m}$ glass-fiber membrane and re-filtered using a $0.45 \mu \mathrm{m}$ nylon membrane. The $\mathrm{pH}$ and salinity of water were analyzed using $\mathrm{pH}$ and salinity meters (PC200 Portable pH/Conductivity Meters, Thomas Scientific, Swedesboro, USA). Merck test kits and the Spectroquant Nova 60 photometer (Merck KGaA, Darmstadt, Germany) were used to determine the levels of chemical oxygen demand (COD), total nitrogen (TN), total phosphorus (TP), ammonium $\left(\mathrm{NH}_{3} / \mathrm{NH}_{4}{ }^{+}\right)$and nitrate $\left(\mathrm{NO}_{3}{ }^{-}\right)$. Total organic carbon (TOC) was measured by the O.I. Analytical Aurora Model 1030 TOC analyzer (OI Analytical, Inc., College Station, TX, USA) (Figure 2). 
TOC
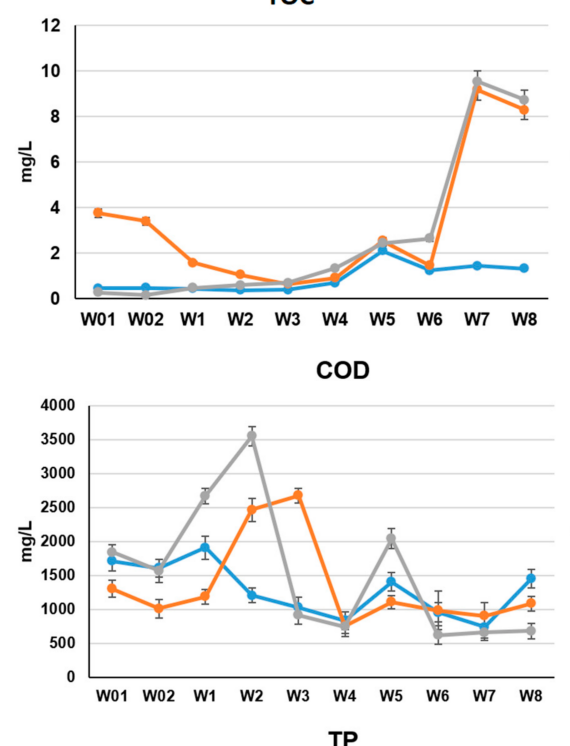

TP

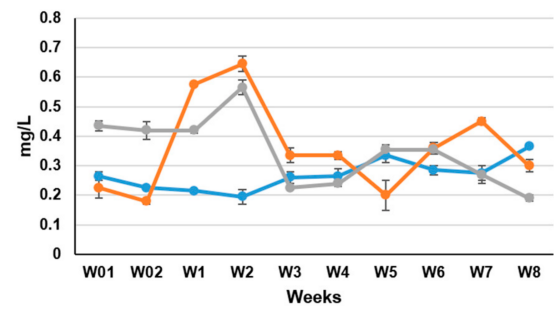

TN
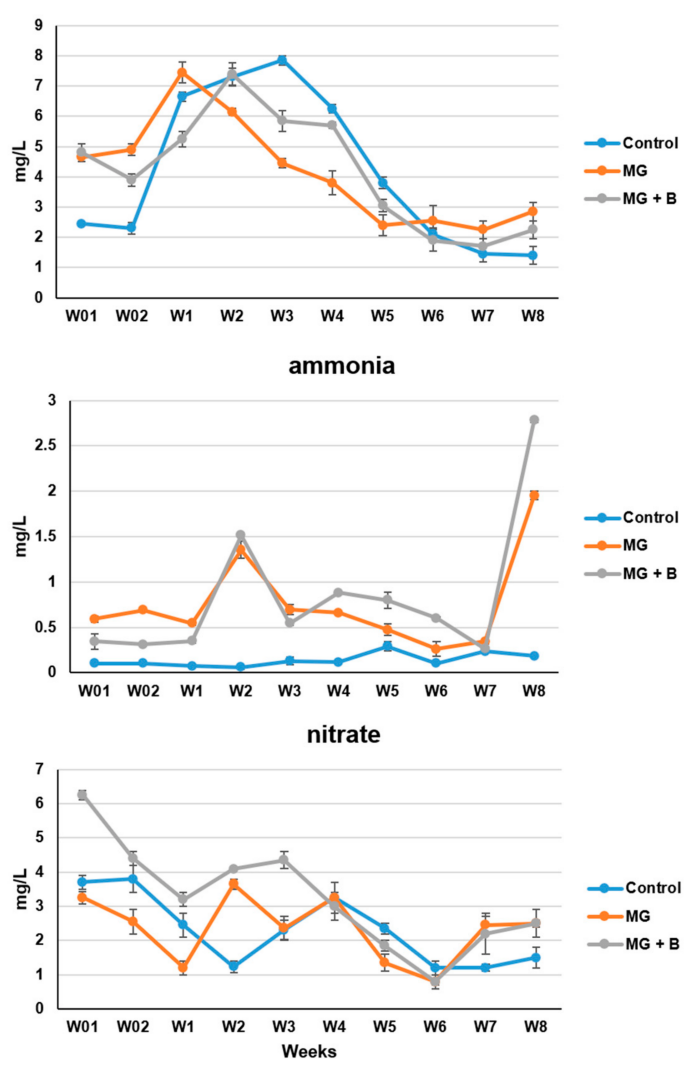

Figure 2. Chemical compositions of water in small milkfish ponds. COD: chemical oxygen demand. TOC: total organic carbon. TP: total phosphorous. TN: total nitrogen. Data from three independent measurements are presented as the mean \pm SE. Control: control small milkfish pond. MG: small milkfish pond with the addition of MG. MG+B: small milkfish pond with the addition of MG and MG-degrading bacteria. W01 and W02: two weeks before the experiment. W1-W8: the first to the 8th week after the start of the experiment.

\subsection{Next-Generation Sequencing and Data Analysis}

Sample DNA was purified using the PowerSoil DNA Isolation kit (QIAGEN, Venlo, Netherlands). The $16 \mathrm{~S}$ rRNA gene sequences containing the V5-V8 variable regions were amplified. The 5' primer contained an adaptor (5'-TCGTCGGCAGCGTCAGATGTGTATAAGAGACAG$\left.3^{\prime}\right)$ and a 16S rRNA gene-specific sequence 341F (5'-CCTACGGGNBGCASCAG-3'). The 3' primer contained the sequence of an adaptor (5'-GTCTCGTGGGCTCGGAGATGTGTATAAGAGACAG$3^{\prime}$ ) and a 16S rRNA gene-specific sequence 805R (5'-GACTACNVGGGTATCTAATCC-3'). The PCRs were performed as described previously [37]. Briefly, the standard $25 \mu \mathrm{L}$ PCR mixture included $1 \times$ PCR buffer containing $1.5 \mathrm{mM} \mathrm{MgCl}_{2}, 200 \mathrm{mM}$ of each deoxynucleotide triphosphate, $10 \mathrm{pmol}$ of each primer, $1.25 \mathrm{U}$ of Taq polymerase, and $50 \mathrm{ng}$ of template DNA. The PCR conditions were as follows: $95^{\circ} \mathrm{C}$ for $10 \mathrm{~min}, 30$ cycles of $95^{\circ} \mathrm{C}$ for $1 \mathrm{~min}$, $55{ }^{\circ} \mathrm{C}$ for $1 \mathrm{~min}$, and $72{ }^{\circ} \mathrm{C}$ for $1 \mathrm{~min}$, and a final extension at $72{ }^{\circ} \mathrm{C}$ for $15 \mathrm{~min}$. After being confirmed by electrophoresis using a 1.2\% $(w / v)$ agarose gel. Next-generation sequencing (NGS) was performed using a MiSeq platform (Illumina, Inc., San Diego, CA, USA) at the Genome Center of the National Yang-Ming University, Taiwan. NGS data produced in this study are available in the National Center for Biotechnology Information (NCBI) by SRA accession: PRJNA646328. Sequence data were analyzed as previously reported [37]. The Trimmomatic (v.0.35, http: / / www.usadellab.org / ) software was used for read trimming. The FLASH (v.1.2.11, https:/ / ccb.jhu.edu/software/FLASH/) software was used to merge paired-end reads. The USEARCH (v.11, http://www.drive5.com/usearch/) software was used to analyze the 16S rRNA gene sequences to remove chimeras. Phylogenetic groups (phylum, class, order, family, genus) were assigned using the classifier 
(16s rRNA training set 18) web tool of the Ribosomal Database Project (RDP Release 11, http:/ / pyro.cme.msu.edu/). A similarity of $95 \%$ was used as the cutoff value for sequence grouping (operational taxonomic units). Microbial genera with the pathways of nitrogen cycle, sulfur cycle, photosynthesis and xenobiotic degradation were retrieved from the Kyoto Encyclopedia of Genes and Genomes (KEGG) module database [43]. A Perl script written by the author was used to find microbial genera present in both of KEGG list and our NGS data. Potential pathogenic bacteria were identified using the information from National Center for Biotechnology Information (NCBI) Pathogen Detection website (https:/ / www.ncbi.nlm.nih.gov/pathogens/). Heatmaps were produced using the heatmap3 package of $\mathrm{R}$ (https: / / www.r-project.org/). The microbial genera differentially present in water and sediment samples were identified by the Mann Whitney $\mathrm{u}$ test. Microbial genera with significant difference $(p$-value $<0.05)$ were chosen to do the Non-metric Multi-dimensional Scaling (NMDS) analysis (Figure 3), heatmap (Figure S2) and Figure S3. NMDS analysis was performed using the metaMDS function in the vegan package of $R$ (https:/ / www.r-project.org/). The result of NMDS analysis was plotted using the ggplot2 package of $R$.

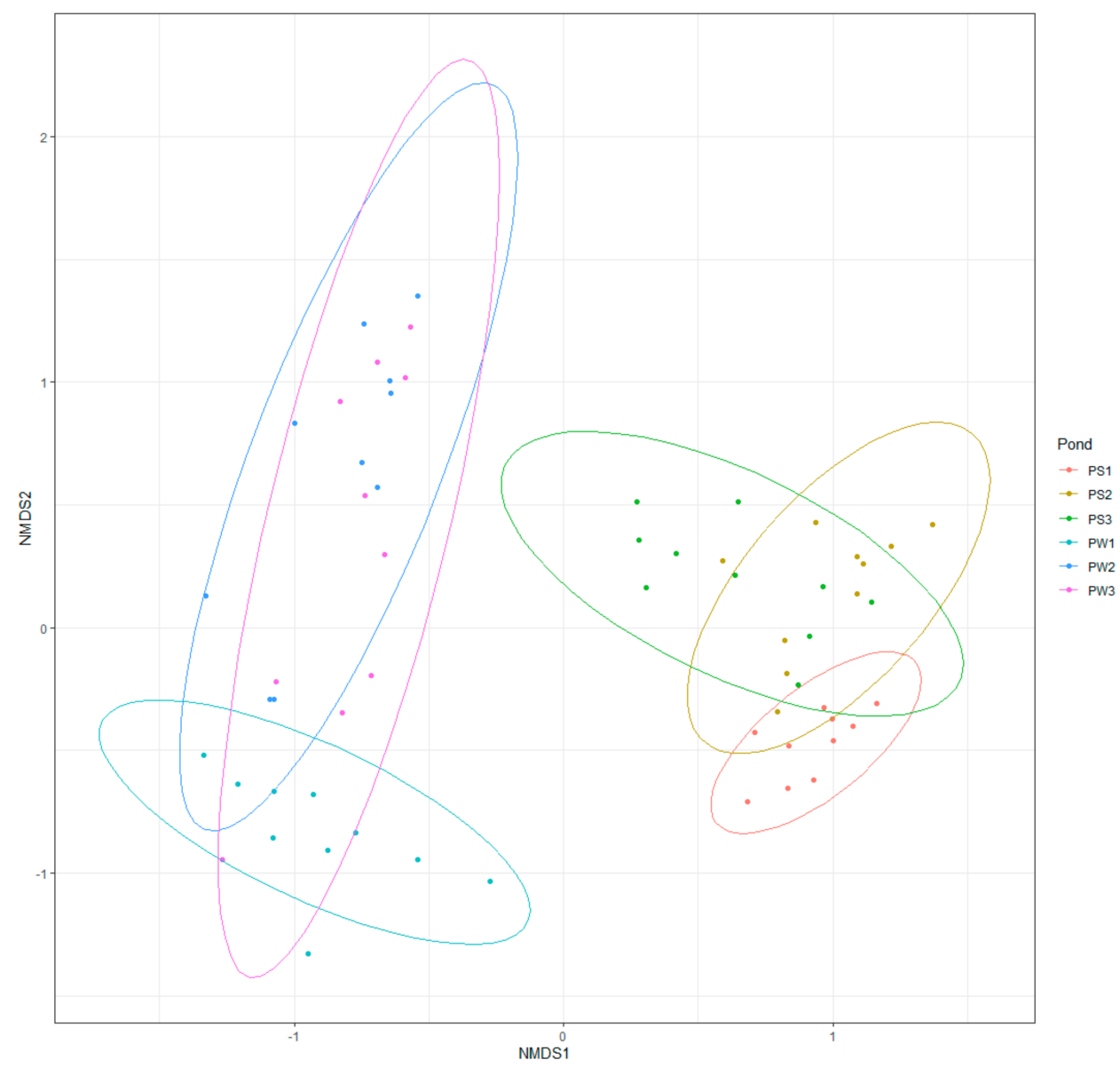

Figure 3. Non-metric Multi-dimensional Scaling (NMDS) analysis of major microbial communities (genus level) among milkfish pond water and sediment. PS: sediment. PW: water. 1: Control small milkfish pond. 2: Small milkfish pond with addition of MG. 3: Small milkfish pond with addition of MG and MG-degrading bacteria.

\section{Results}

\subsection{Effects of $M G$ and MGDB on the Water Quality of Small MCPs}

The presence of MG in the water and sediment samples from the small MCPs were analyzed by HPLC. As shown in Table 1, MG in the water samples was not detected on the 14th day for ponds 2 and 3. In contrast, MG at $0.1 \pm 0.05 \mathrm{mg} / \mathrm{kg}$ was detected in 
the sediment of pond 2 (without the addition of MGDB), and was not detected in the sediment of pond 3 (with the addition of MGDB) on the 56th day. These results indicate that even when MGDB were present, MG degradation in sediment was much slower than MG degradation in water.

Table 1. Malachite green degradation in small milkfish ponds.

\begin{tabular}{ccccccc}
\hline & $\begin{array}{c}\text { Water } \\
(\mathbf{m g} / \mathbf{L})\end{array}$ & & \multicolumn{5}{c}{$\begin{array}{c}\text { Sediment } \\
\mathbf{( m g / K g})\end{array}$} \\
\hline Day & Pond 1 & Pond 2 & Pond 3 & Pond 1 & Pond 2 & Pond 3 \\
\hline 0 & ND & $1.95 \pm 0.22$ & $1.92 \pm 0.31$ & ND & $1.98 \pm 0.42$ & $1.90 \pm 0.29$ \\
7 & ND & $1.58 \pm 0.18$ & $1.45 \pm 0.29$ & ND & $1.73 \pm 0.26$ & $1.52 \pm 0.22$ \\
14 & ND & ND & ND & ND & $1.29 \pm 0.32$ & $1.08 \pm 0.19$ \\
21 & ND & ND & ND & ND & $1.02 \pm 0.12$ & $0.91 \pm 0.12$ \\
28 & ND & ND & ND & ND & $0.82 \pm 0.10$ & $0.75 \pm 0.09$ \\
35 & ND & ND & ND & ND & $0.68 \pm 0.09$ & $0.42 \pm 0.08$ \\
42 & ND & ND & ND & ND & $0.35 \pm 0.06$ & $0.12 \pm 0.05$ \\
49 & ND & ND & ND & ND & $0.21 \pm 0.08$ & $0.07 \pm 0.01$ \\
56 & ND & ND & ND & ND & $0.10 \pm 0.05$ & ND \\
\hline
\end{tabular}

Pond 1: control. Pond 2: addition of malachite green. Pond 3: addition of malachite green and malachite green-degrading bacteria. ND: Not detected.

The quality of the small MCP water was assessed by analyzing the chemical compositions in the water samples. As shown in Figure 2, in comparison to pond 1, ponds 2 and 3 exhibited higher TP (between week 1 and week 4), TOC (between week 7 and week 8), COD (between week 1 and week 3 ) and ammonium (overall the experimental period) levels. In contrast, ponds 2 and 3 exhibited lower TN levels than pond 1 between week 3 and week 5 (Figure 2). The addition of MGDB did not alleviate the effects of MG on the levels of TOC, COD, TP, TN, ammonium and nitrate (Figure 2). The $\mathrm{pH}$ values of the water in ponds 2 and 3 were increased (Figure S1). Since small MCPs are closed systems, the evaporation of water caused the salinity of all three ponds to increase (Figure S1).

\subsection{Effects of MG and MGDB on the Microbial Communities of Small MCPS}

NGS of the 16S rRNA gene was used to analyze the microbial communities in the water and sediment of the small MCPs. Cluster analysis and principal component analysis indicated that diverse microbial community compositions among the water and sediment of the three MCPs (Figure 3, Figures S2 and S3). These results suggested that the addition of MG led to dramatic changes in the microbial community compositions in the water and sediment of the small MCP. The addition of MGDB could not prevent changes of the microbial communities in the water and sediment of the small MCP.

\subsection{Effects of MG and MGDB on Nitrogen Cycle-Associated Microbial Communities in Small MCP}

The proper balance of microbes associated in ammonium metabolism (nitrogen cycle) has a great influence on the quality of water environments $[37,44,45]$. Therefore, the ammonium metabolism (nitrogen cycle)-associated microbial communities in the small MCPs was examined. The first microbial group that exhibited dramatic proportional changes after the addition of $\mathrm{MG}$ was the nitrogen fixation-associated microbes that converted nitrogen $\left(\mathrm{N}_{2}\right)$ into ammonium $\left(\mathrm{NH}_{3} / \mathrm{NH}_{4}{ }^{+}\right)$in small MCP sediment (Figure $\left.4 \mathrm{~A}\right)$. The second microbial group that exhibited dramatic proportional changes after the addition of $\mathrm{MG}$ was the denitrification-associated microbes that converted nitrate $\left(\mathrm{NO}_{3}{ }^{-}\right)$into nitrogen $\left(\mathrm{N}_{2}\right)$ in small MCP sediment (Figure $4 \mathrm{~B}$ ). The third microbial group that exhibited dramatic proportional changes after the addition of $\mathrm{MG}$ was the assimilatory nitrate reductionassociated microbes that converted nitrate $\left(\mathrm{NO}_{3}{ }^{-}\right)$into ammonium $\left(\mathrm{NH}_{3} / \mathrm{NH}_{4}{ }^{+}\right)$in small MCP sediment (Figure 5A). Although the microbial communities associated with anammox (ammonia $=>$ nitrogen) also exhibited proportional changes after the addition of MG 
(Figure 5B), the overall proportion of this group was very low $\left(8.6 \times 10^{-5}\right)$ and may have little influence. The fourth microbial group that exhibited proportional and compositional changes after the addition of MG was the dissimilatory nitrate reduction-associated microbes that converted nitrate $\left(\mathrm{NO}_{3}{ }^{-}\right)$into ammonium $\left(\mathrm{NH}_{3} / \mathrm{NH}_{4}{ }^{+}\right)$in small MCP water and sediment (Figure 6A). The microbial communities associated with nitrification (ammonia $=>$ nitrite) exhibited minimal change (Figure 6B). Overall, the addition of MG led to dramatic increase in microbial communities that could lead to an increase in ammonium levels. These results are consistent with the high ammonium levels in ponds 2 and 3 (compared with the levels in pond 1) (Figure 2). The addition of MGDB reduced part of the effects of MG on the nitrogen cycle-associated microbial community compositions (Figures 4-6). However, the increase in ammonium levels did not revert.

\subsection{Effects of MG and MGDB on Algal, Cyanobacterial and Phototrophic Bacterial Communities in Small MCPS}

Cyanobacteria and algae are important members of the ammonium metabolismassociated microbial community. As shown in Figure 7A, cyanobacteria were present in higher proportions in the water of ponds 2 and 3 than in pond 1 . However, proportions of the algal communities exhibited minimal changes. These results suggested that the addition of MG led to cyanobacterial blooms. The addition of MG-degrading bacteria (pond 3) did not reverse the effect of MG on cyanobacterial blooms. These results are consistent with the results in Figures 2-6 that the addition of MG led to a change in nitrogen cycle-associated microbial communities and, as a consequence, led to an increase in ammonium levels. High ammonium levels in ponds 2 and 3 (compared with pond 1) may have resulted in cyanobacterial blooms. In contrast, anoxygenic phototrophic bacteria including genera of purple sulfur bacteria, purple nonsulfur bacteria, and green sulfur bacteria decreased in ponds 2 and 3 (Figure 7B). However, the DO levels were not different between ponds (Figure S1). These results suggest that the addition of MG led to a decrease in anoxygenic phototrophic bacteria and an increase in oxygenic phototrophic microbes (cyanobacteria). The addition of MGDB did not alleviate the effects of MG on oxygenic and anoxygenic phototrophic microbial communities.

\subsection{Effects of MG and MGDB on Pathogenic and Xenobiotic-Degrading Microbial Communities} in Small MCPs

The major goal of adding MG to aquaculture ponds is to prevent infectious diseases. As shown in Figure S4, the proportions of potential pathogenic bacteria decreased with the addition of MG in small MCP water. The effects of MG on pathogenic bacteria were not reversed by the addition of MGDB. The proportions of xenobiotic-degrading microbial communities decreased with the addition of MG in small MCP water and sediment (Figure S5). The effects of MG on xenobiotic-degrading microbial communities were not reversed by the addition of MGDB to small MCP water.

\subsection{Model of MG and MGDB on Nitrogen Metabolism-Associated Microbiome in Small MCPs}

Based on the results shown in Figures 2-7, a graphic illustration of the interactions among nitrogen metabolism, microbial communities and MG addition/biodegradation in small MCPs was proposed (Figure 8). The addition of MG (pond 2) increased the nitrogen fixation, denitrification and assimilatory nitrate reduction associated microbial communities, which might lead to increased ammonium levels and, as a consequence, cyanobacterial blooms. The addition of MGDB (pond 3) reversed a part of the effects of MG on nitrogen cycle-associated microbial communities but was not strong enough to prevent cyanobacterial blooms. 

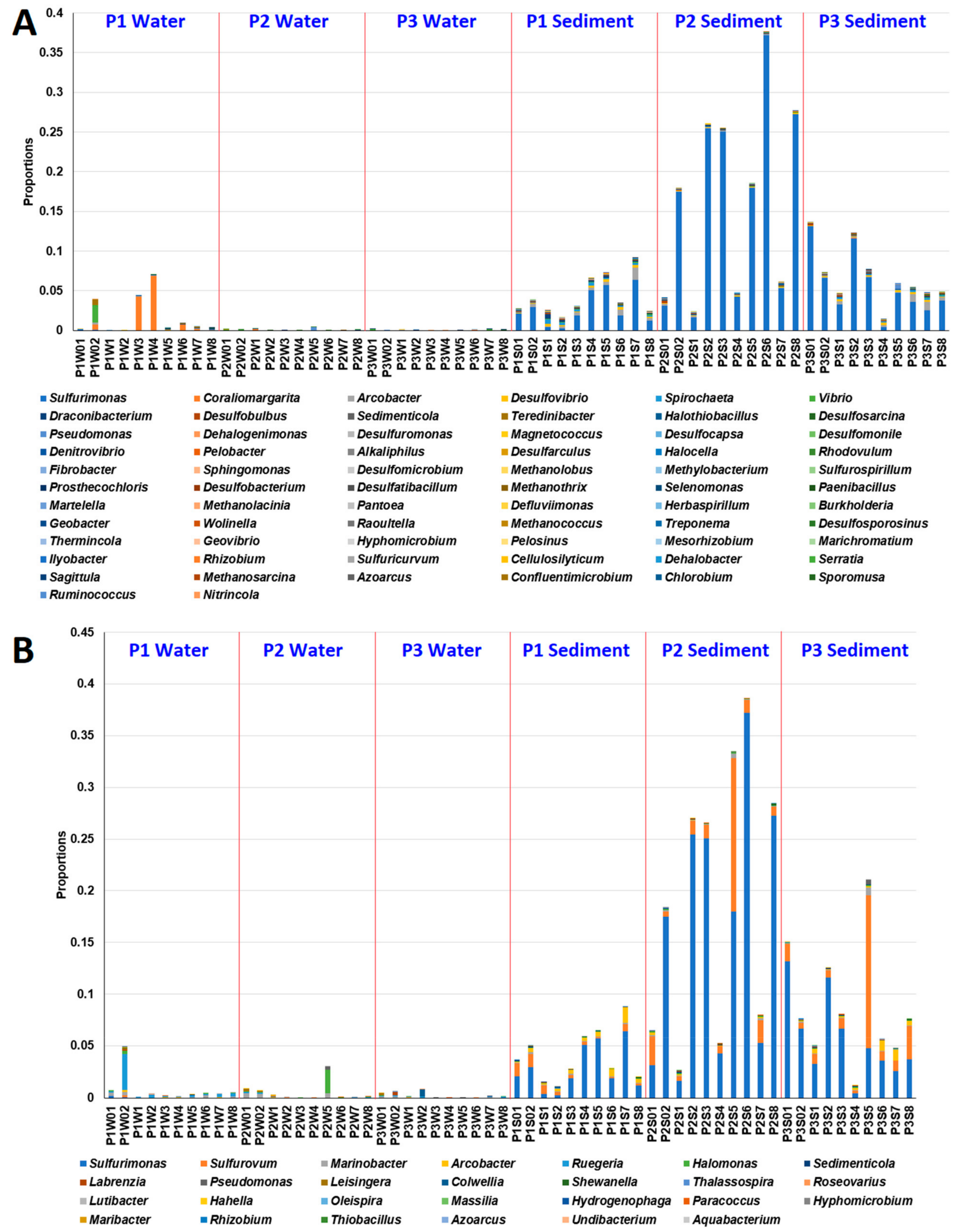

Figure 4. Proportions of nitrogen fixation (nitrogen $=>$ ammonia) (A) and denitrification (nitrate $=>$ nitrogen) $(\mathbf{B})$ associated microbial communities among the water and sediment of small milkfish ponds. P1: control small milkfish pond. P2: small milkfish pond with the addition of MG. P3: small milkfish pond with the addition of MG and MG-degrading bacteria. 

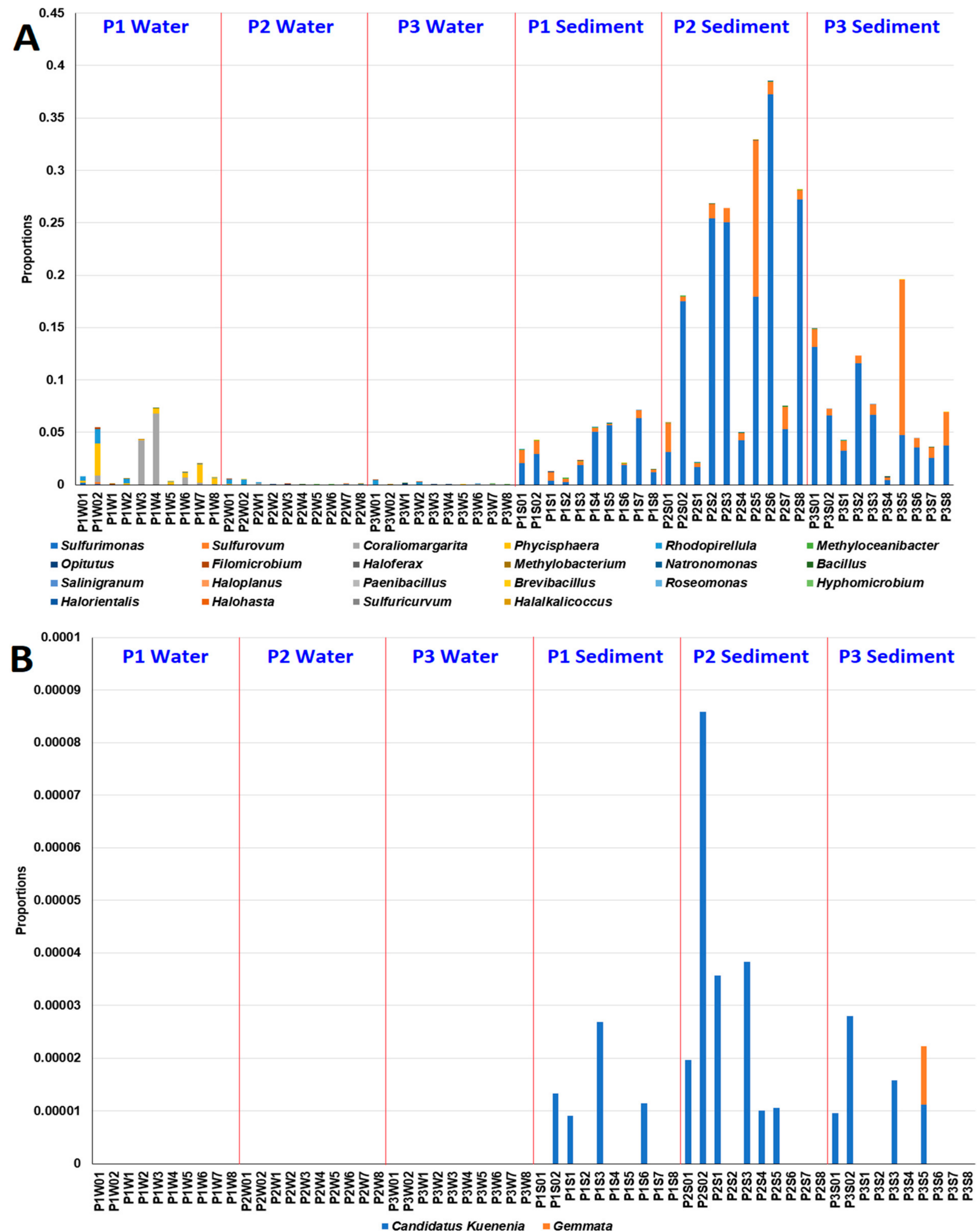

Figure 5. Proportions of assimilatory nitrate reduction (nitrate $=>$ ammonia) (A) and anammox (ammonia $=>$ nitrogen) (B) associated microbial communities among the water and sediment of small milkfish ponds. P1: control small milkfish pond. P2: small milkfish pond with the addition of MG. P3: small milkfish pond with the addition of MG and MGdegrading bacteria. 

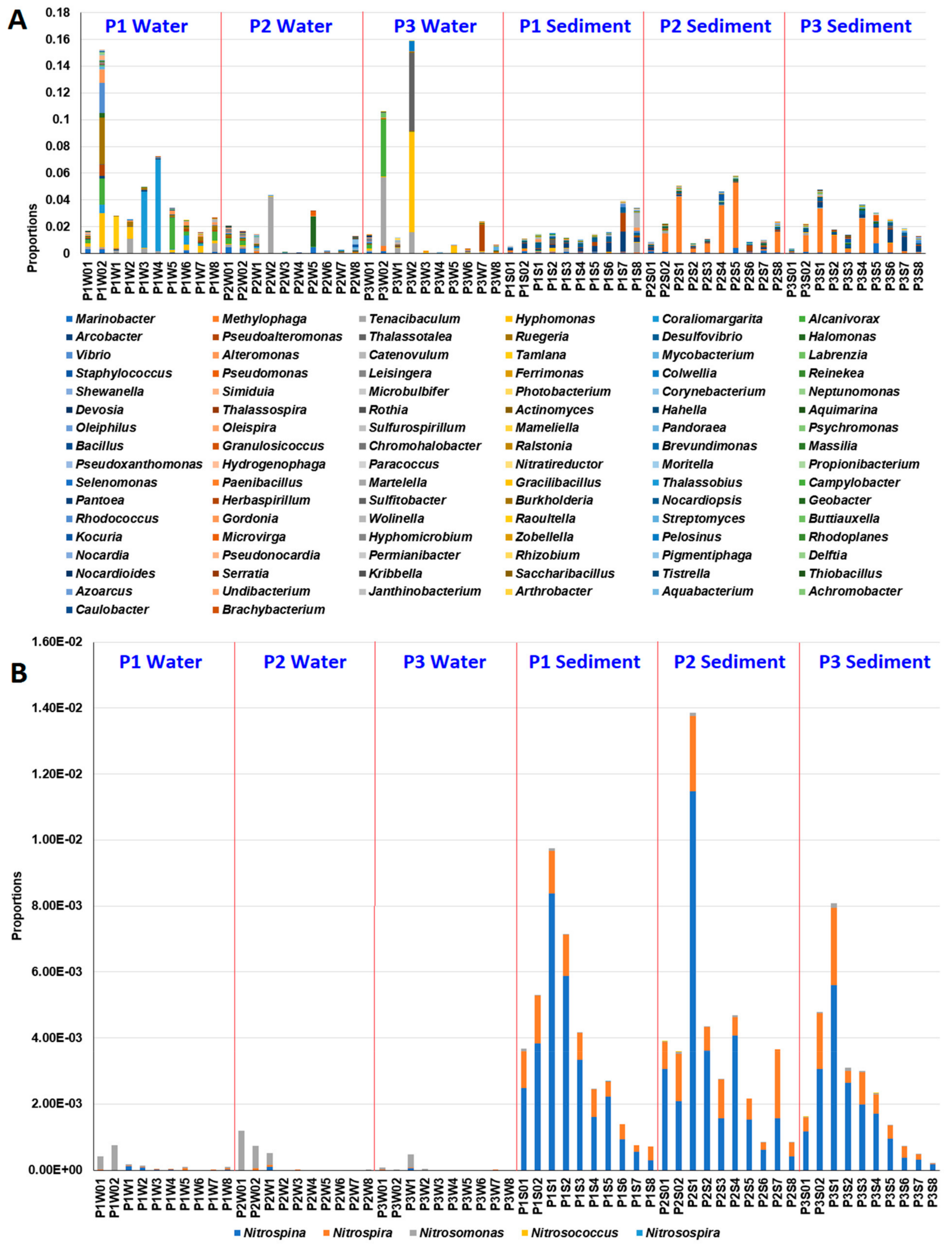

Figure 6. Proportions of dissimilatory nitrate reduction (nitrate $=>$ ammonia) $($ A) and nitrification (ammonia $=>$ nitrite) (B) associated microbial communities among the water and sediment of small milkfish ponds. P1: control small milkfish pond. P2: small milkfish pond with the addition of MG. P3: small milkfish pond with the addition of MG and MGdegrading bacteria. 

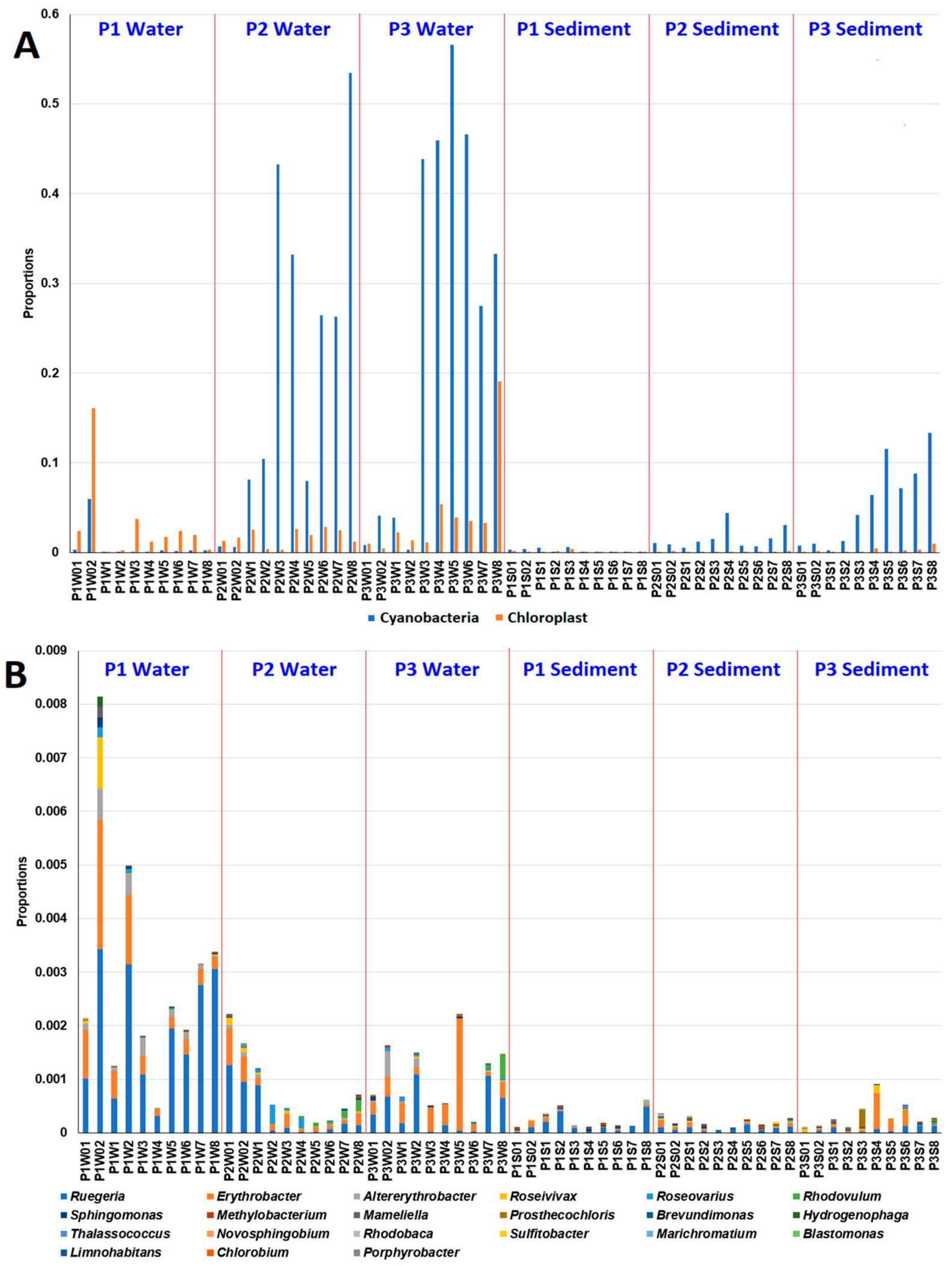

Figure 7. Proportions of phototrophic microbial communities. (A) Cyanobacterial and algal and communities and (B) anoxygenic phototrophic bacterial communities among the water and sediment of small milkfish ponds. P1: control small milkfish pond. P2: small milkfish pond with the addition of MG. P3: small milkfish pond with the addition of MG and MG-degrading bacteria. 

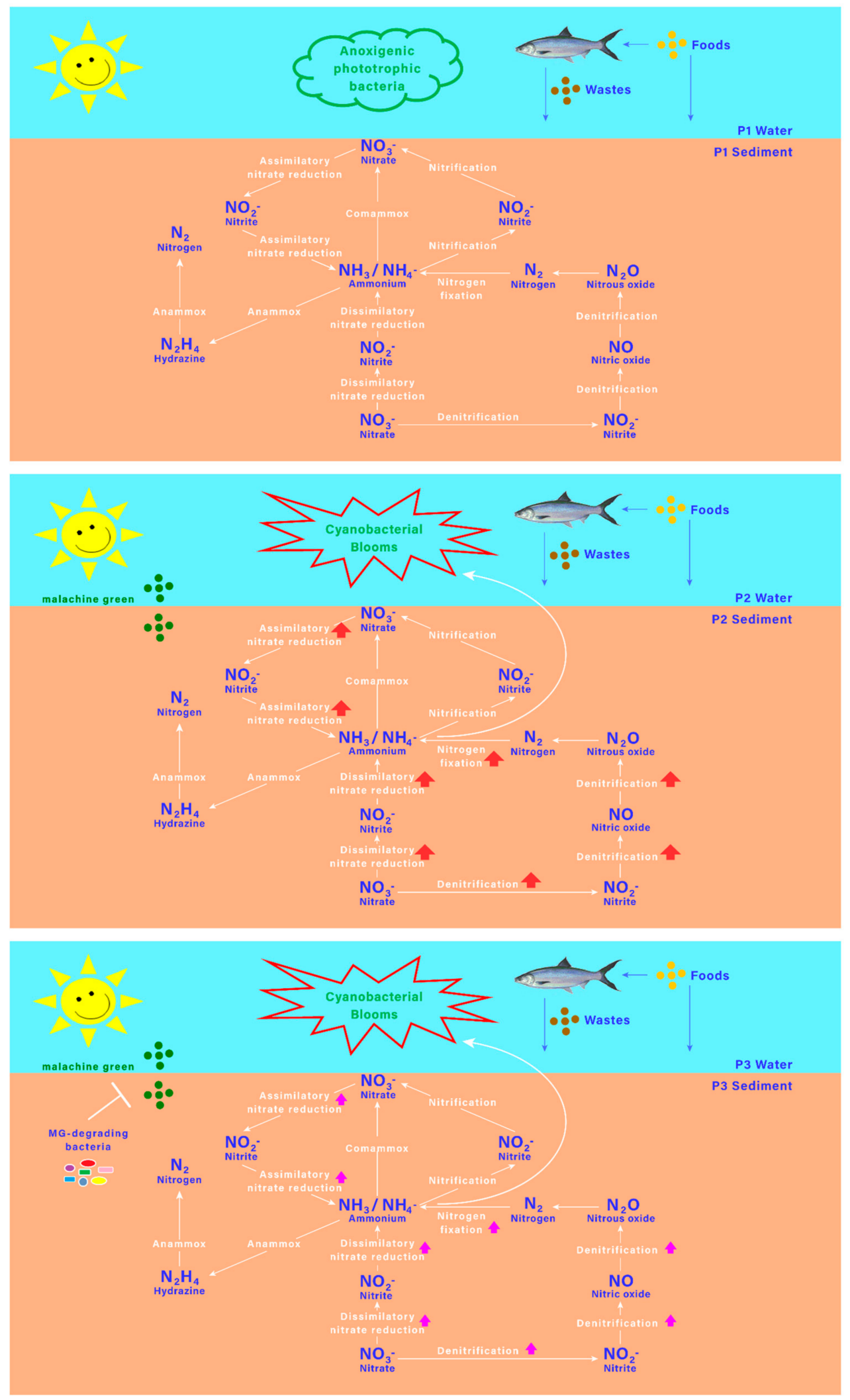

Figure 8. Summary of effects of malachite green on nitrogen cycle-associated microbial communities among the water and sediment of small milkfish ponds. P1: control small milkfish pond. P2: small milkfish pond with the addition of MG. P3: small milkfish pond with the addition of MG and MG-degrading bacteria. 


\section{Discussion}

The study of Gobler et al. (2016) indicates that cyanobacteria such as Microcystis exhibit physiological adaptations to dominate low-P surface waters [46]. Nitrogen loading was shown to selectively raise the abundance of Microcystis and Planktothrix. Newell et al. (2019) demonstrated that reduced forms of nitrogen are drivers of harmful cyanobacterial blooms [47]. Killberg-Thoreson et al. (2020) demonstrated that the magnitude of uptake rates by bloom of Alexandrium monilatum generally follow the pattern of ammonium $\left(\mathrm{NH}_{4}{ }^{+}\right)$ $>$ nitrate $\left(\mathrm{NO}_{3}{ }^{-}\right)>$urea $>$amino acids $>$nitrite $\left(\mathrm{NO}_{2}{ }^{-}\right)$[48]. The relationship between the metabolism of cyanobacteria and chemical oxygen demand (COD) in Dianchi Lake and the causes of this relationship were examined in the study by He et al. (2019) [49]. Organic substances containing nitrogen and sugars lead to an increase in COD to a certain extent. COD levels between 4.5 and $7.5 \mathrm{mg} / \mathrm{L}$ is ideal for lake water to reduce microbial activity and associated bicarbonate production. Reduction in nutrients and bicarbonate levels will prevent excess cyanobacteria growth. Overall, the rise of $\mathrm{pH}, \mathrm{NH}_{4}{ }^{+}$, phosphate, and COD are highly associated with the occurrence of cyanobacterial blooms [50]. These results are consistent with the observations of this study after adding MG to pond 2 (Figure 2 and Figure S1).

Since anoxygenic phototrophic bacteria lack carbon fixation capacity and depend on organic carbon dissolved organic matter (DOM) substrates, they must be regarded as secondary producers due to their role in recycling DOM [51]. Zhang et al. (2014) demonstrated that water supplementation with anoxygenic phototrophic bacteria (the purple nonsulfur bacteria Rhodopseudomonas palustris) could significantly decrease the number of nitrite reducers and anaerobic bacteria [52]. Therefore, the addition of anoxygenic phototrophic bacteria to water changes the microbial community structure and improves the water quality. Anoxygenic phototrophic bacteria are also frequently used as beneficial bacteria for aquaculture [53,54]. Therefore, a decrease in anoxygenic phototrophic bacteria after the addition of MG is harmful for DOM recycling and water quality in small MCPs (Figure 7).

The addition of MGDB did not prevent cyanobacterial blooms. This result is not consistent with that of our previous study that addition of sulfamethoxazole-degrading bacteria reversed the effects of sulfamethoxazole (SMX) and prevented cyanobacterial blooms [37]. The different results may be due to the different properties of MG and SMX. In the SMX experiments, SMX was distributed in the water of small MCPs and degraded during the 4th week. In contrast, MG was persistent in the sediment of small MCPs until the 7 th week (Table 1).

Study of Kowaltowski et al. (1999) demonstrated that MG induced a dissipation of mitochondrial membrane potential, accompanied by mitochondrial swelling. These results indicating that MG induce mitochondrial permeability transition and followed by respiratory inhibition [55]. MG is believed to disturb the activity of glutathione S-transferase activities [56,57]. The cytotoxicity of MG was associated with an increase in lipid peroxidation and the formation of free radicals [58,59] and DNA damage [60,61]. Muller and Gautier (1975) reported that malachite green binds to DNA with a preference for A:T-rich areas [62]. This observation was supported by the study of Fox et al. (1992), which showed that malachite green bound preferentially to A:T-rich regions [63]. Wolfe (1977) showed that malachite green inhibited E. coli polymerase I-catalyzed DNA replication in vitro, possibly by blocking enzyme progression [64]. In summary, MG have multiple targets in both prokaryotic and eukaryotic cells and exhibit a broad spectrum of toxicities. Therefore, although the potential pathogenic bacteria in small MCPs were reduced. The beneficial bacteria (such as anoxygenic phototrophic bacteria and xenobiotic-degrading microbes) in small MCPs were also reduced.

\section{Conclusions}

A set of small MCPs was used as a model system to determine the effects of MG on the water quality and microbial communities in the small MCPs. The interactions between antimicrobials, water quality and microbial communities in the small MCPs were demon- 
strated. Cyanobacterial blooms occurred in the water of the small MCP with the addition of MG and cannot be completely reversed by the addition of MGDB. Metagenomic analysis of microbial communities revealed that the occurrence of cyanobacterial blooms may be due to increased levels of ammonium by reduction of nitrogen cycle-associated (nitrogen fixation, assimilatory nitrate reduction, dissimilatory nitrate reduction and anammox) microbial communities. The communities of anoxygenic phototrophic bacteria, which are beneficial for aquaculture and aquatic ecosystems, were also reduced by the addition of MG. The results of this study reveal not only the adverse effects of MG in aquaculture but also the difficulties of bioremediation for aquatic environments polluted by MG.

Supplementary Materials: The following are available online at https:/ /www.mdpi.com/2073-444 1/13/4/411/s1, Figure S1. Water quality of small milkfish ponds. DO: dissolved oxygen. Figure S2. Cluster analysis of major microbial communities (252 genera) among milkfish pond water and sediment. Figure S3. Proportions of archaeal communities (phyla) among the water and sediment of milkfish ponds. Figure S4. Proportions of potential pathogenic microbial communities among the water and sediment of milkfish ponds. Figure S5. Proportions of xenobiotic-degrading microbial communities among the water and sediment of milkfish ponds.

Author Contributions: Formal analysis, C.-W.Y. and C.-Y.H.; Funding acquisition, B.-V.C.; Investigation, C.-W.Y.; Methodology, Y.-T.C. and C.-Y.H.; Project administration, B.-V.C.; Writing-original draft, C.-W.Y. and B.-V.C.; Writing-review \& editing, C.-W.Y. and B.-V.C. All authors have read and agreed to the published version of the manuscript.

Funding: This research was supported by the Ministry of Science and Technology, Taiwan (grant no. MOST 109-2311-B-031-001).

Institutional Review Board Statement: Not applicable.

Informed Consent Statement: Not applicable.

Data Availability Statement: Not applicable.

Conflicts of Interest: The authors declare no conflict of interest.

\section{References}

1. FAO. The State of World Fisheries and Aquaculture 2020: Sustainability in Action; FAO: Rome, Italy, 2020; pp. 21-22.

2. Bagarinao, T. Systematics, distribution, genetics and life history of Milkfish Chanos chanos. Environ. Biol. Fish. 1994, 39, 25-41. [CrossRef]

3. Martinez, F.S.; Tseng, M.C.; Yeh, S.P. Milkfish (Chanos chanos) culture: Situations and trends. J. Fish. Soc. Taiwan 2006, 33, 229-244.

4. Pulkkinen, K.; Suomalainen, L.R.; Read, A.F.; Ebert, D.; Rintamäki, P.; Valtonen, E.T. Intensive fish farming and the evolution of pathogen virulence: The case of columnaris disease in Finland. Proc. Biol. Sci. 2010, 77, 593-600. [CrossRef] [PubMed]

5. Soliman, W.S.; Shaapan, R.M.; Mohamed, L.A.; Gayed, S.S.R. Recent biocontrol measures for fish bacterial diseases, in particular to probiotics, bio-encapsulated vaccines, and phage therapy. Open Vet. J. 2019, 9, 190-195. [CrossRef]

6. Alderman, D.J. Trends in therapy and prophylaxis 1991-2001. Bul. Eur. Assoc. Fish Pathol. 2002, 22, 117-125.

7. Campbell, R.E.; Lilley, J.H.; Taukhid, V.P.; Kanchanakhan, S. In vitro screening of novel treatments for Aphanomyces invadans. Aquacult. Res. 2001, 32, 223-233. [CrossRef]

8. Diggles, B.K. A mycosis of juvenile spiny rock lobster, Jasus edwardsii caused by Haliphthoros sp., and possible methods of chemical control. J. Fish Dis. 2001, 24, 99-110. [CrossRef]

9. Diggles, B.K. Chemotherapy of the ciliate Trichodina sp. on juvenile turbot with notes on the susceptibility of fish with abnormal pigmentation. N. Z. J. Mar. Freshw. Res. 2000, 34, 645-652. [CrossRef]

10. Madsen, H.C.K.; Buchmann, K.; Mellergaard, S. Treatment of trichodiniasis in eel (Anguilla anguilla) reared in recirculation systems in Denmark: Alternatives to formaldehyde. Aquaculture 2000, 186, 221-231. [CrossRef]

11. Rodriguez, J.L.T.; Fernandez, M.T.S. Attempts at oral pharmacological treatment of Ichthyophthirius multifiliis in rainbow trout, Oncorhynchus mykiss. J. Fish Dis. 2001, 24, 249-252. [CrossRef]

12. Tieman, D.M.; Goodwin, A.E. Treatments for itch infestations in channel catfish evaluated under static and flow-through water conditions. N. Am. J. Aquacult. 2001, 63, 293-299. [CrossRef]

13. Flores, C.J.; Flores, C.R.; Ibarra, V.F.; Vera-Montenegro, Y.; Vasquez, P.C. Evaluation of chemotherapeutic drugs against cichlidogyriasis in tilapia fish (Oreochromis hornorum) in Mexico. Rev. Latinoam. Microbiol. 1995, 37, 179-187.

14. Gouvello, R.; Pobel, T.; Richards, R.H.; Gould, C. Field efficacy of a ten days treatment of fumagillin against proliferative kidney disease in rainbow trout, Oncorhynchus mykiss. Aquaculture 1999, 171, 27-40. [CrossRef] 
15. Molnar, K. Effect of exposure to malachite green solution on common carp fry with Dactylogyrus vastator (monogenea) infection. Acta. Vet. Hung. 1995, 43, 277-286. [PubMed]

16. Srivastava, S.; Sinha, R.; Roy, D. Toxicological effects of malachite green. Aquat. Toxicol. 2004, 66, 319-329. [CrossRef] [PubMed]

17. Pipoyan, D.; Stepanyan, S.; Beglaryan, M.; Stepanyan, S.; Mantovani, A. Health risk assessment of toxicologically relevant residues in emerging countries: A pilot study on Malachite Green residues in farmed freshwater fish of Armenia. Food Chem. Toxicol. 2020, 143, 111526. [CrossRef]

18. Dubreil, E.; Mompelat, S.; Kromer, V.; Guitton, Y.; Danion, M.; Morin, T.; Hurtaud-Pessel, D.; Verdon, E. Dye residues in aquaculture products: Targeted and metabolomics mass spectrometric approaches to track their abuse. Food Chem. 2019, 294, 355-367. [CrossRef]

19. Chu, Y.L.; Chimeddulam, D.; Sheen, L.Y.; Wu, K.Y. Probabilistic risk assessment of exposure to leucomalachite green residues from fish products. Food Chem. Toxicol. 2013, 62, 770-776. [CrossRef]

20. Zhou, X.; Zhang, J.; Pan, Z.; Li, D. Review of methods for the detection and determination of malachite green and leuco-malachite green in aquaculture. Crit. Rev. Anal. Chem. 2019, 49, 1-20. [CrossRef]

21. Adel, M.; Dadar, M.; Oliveri, C.G. Antibiotics and malachite green residues in farmed rainbow trout (Oncorhynchus mykiss) from the Iranian markets: A risk assessment. Int. J. Food Prop. 2017, 20, 402-408. [CrossRef]

22. Chen, Y.; Xia, S.; Han, X.; Fu, Z. Simultaneous Determination of Malachite Green, Chloramphenicols, Sulfonamides, and Fluoroquinolones Residues in Fish by Liquid Chromatography-Mass Spectrometry. J. Anal. Methods Chem. 2020, $2020,3725618$. [CrossRef] [PubMed]

23. Wei, S.-C.; Fan, S.; Lien, C.-W.; Unnikrishnan, B.; Wang, Y.-S.; Chu, H.-W.; Huang, C.-C.; Hsu, P.-H.; Chang, H.-T. Graphene oxide membrane as an efficient extraction and ionization substrate for spray-mass spectrometric analysis of malachite green and its metabolite in fish samples. Anal. Chim. Acta. 2018, 1003, 42-48. [CrossRef] [PubMed]

24. Hashimoto, J.C.; Rizzato, J.A.; Ferraz de Queiroz, J.; Reyes, F.G. Considerations on the use of malachite green in aquaculture and analytical aspects of determining the residues in fish: A review. J. Aquat. Food Prod. Technol. 2011, 20, 273-294. [CrossRef]

25. Barani, A.; Tajik, H. Malachite green residue in farmed fish in north-west part of Iran. Int. J. Food Prop. 2017, 20, S580-S585. [CrossRef]

26. Donya, S.M.; A Farghaly, A.; A Abo-Zeid, M.; Aly, H.F.; A Ali, S.; A Hamed, M.; El-Rigal, N.S. Malachite green induces genotoxic effect and biochemical disturbances in mice. Eur. Rev. Med. Pharmacol. Sci. 2012, 16, 469-482.

27. Culp, S.J.; Mellick, P.W.; Trotter, R.W.; Greenlees, K.J.; Kodell, R.L.; Beland, F.A. Carcinogenicity of malachite green chloride and leucomalachite green in B6C3F1 mice and F344 rats. Food Chem. Toxicol. 2006, 44, 1204-1212. [CrossRef]

28. National Toxicology Program. Toxicology and Carcinogenesis Studies of Malachite Green Chloride and Leucomalachite Green. (CAS NOS. 569-64-2 and 129-73-7) in F344/N Rats and B6C3F1 Mice (Feed Studies); Technical Report Series (National Toxicology Program (U.S.)), no. 527; U.S. Dept. of Health and Human Services, National Toxicology Program: Washington, DC, USA, $2005 ;$ pp. 1-312.

29. Yao, X.; Zhang, Y.; Zhang, L.; Zhou, Y. A bibliometric review of nitrogen research in eutrophic lakes and reservoirs. J. Environ. Sci. 2018, 66, 274-285. [CrossRef]

30. Liang, Z.; Soranno, P.A.; Wagner, T. The role of phosphorus and nitrogen on chlorophyll a: Evidence from hundreds of lakes. Water Res. 2020, 185, 116236. [CrossRef] [PubMed]

31. Huisman, J.; Codd, G.A.; Paerl, H.W.; Ibelings, B.W.; Verspagen, J.M.H.; Visser, P.M. Cyanobacterial blooms. Nat. Rev. Microbiol. 2018, 16, 471-483. [CrossRef]

32. Ndlela, L.L.; Oberholster, P.J.; Van Wyk, J.H.; Cheng, P.H. Bacteria as biological control agents of freshwater cyanobacteria: Is it feasible beyond the laboratory? Appl. Microbiol. Biotechnol. 2018, 102, 9911-9923. [CrossRef]

33. Pal, M.; Yesankar, P.J.; Dwivedi, A.; Qureshi, A. Biotic control of harmful algal blooms (HABs): A brief review. J. Environ. Manag. 2020, 268, 110687. [CrossRef] [PubMed]

34. Lopes, R.B.; Olinda, R.A.; Souza, B.A.; Cyrino, J.E.; Dias, C.T.; Queiroz, J.F.; Tavares, L.H. Efficiency of bioaugmentation in the removal of organic matter in aquaculture systems. Braz. J. Biol. 2011, 71, 409-419. [CrossRef] [PubMed]

35. Maria Gabriela, P.F.; Fabiana, P.M.; João Paulo, V.L.; Humber, A.A.; William, S.; Eudes, S.C. Bioremediation and biocontrol of commercial probiotic in marine shrimp culture with biofloc. Lat. Am. J. Aquat. Res. 2017, 45, 167-176.

36. Zhou, Q.; Li, K.; Jun, X.; Bo, L. Role and functions of beneficial microorganisms in sustainable aquaculture. Bioresour. Technol. 2009, 100, 3780-3786. [CrossRef] [PubMed]

37. Chang, B.V.; Chang, Y.T.; Chao, W.L.; Yeh, S.L.; Kuo, D.L.; Yang, C.W. Effects of sulfamethoxazole and sulfamethoxazole-degrading bacteria on water quality and microbial communities in milkfish ponds. Environ. Pollut. 2019, 252, 305-316. [CrossRef]

38. Song, J.; Han, G.; Wang, Y.; Jiang, X.; Zhao, D.; Li, M.; Yang, Z.; Ma, Q.; Parales, R.E.; Ruan, Z.; et al. Pathway and kinetics of malachite green biodegradation by Pseudomonas veronii. Sci. Rep. 2020, 10, 4502. [CrossRef]

39. Tao, Y.; Meng, L.; Guo, Y.; Han, M.; Sun, C.; Wang, F.; Li, J. Biological Decolorization and Degradation of Malachite Green by Pseudomonas sp. YB2: Process Optimization and Biodegradation Pathway. Curr. Microbiol. 2017, 74, 1210-1215. [CrossRef]

40. Vignesh, A.; Manigundan, K.; Santhoshkumar, J.; Shanmugasundaram, T.; Gopikrishnan, V.; Radhakrishnan, M.; Joseph, J.; Ayyasamy, P.M.; Kumar, G.D.; Meganathan, R.; et al. Microbial degradation, spectral analysis and toxicological assessment of malachite green by Streptomyces chrestomyceticus S20. Bioprocess Biosyst. Eng. 2020, 43, 1457-1468. [CrossRef]

41. Wang, J.; Gao, F.; Liu, Z.; Qiao, M.; Niu, X.; Zhang, K.-Q.; Huang, X. Pathway and molecular mechanisms for malachite green biodegradation in Exiguobacterium sp. MG2. PLoS ONE 2012, 7, e51808. [CrossRef] 
42. Yang, C.W.; Chao, W.L.; Hsieh, C.Y.; Chang, B.V. Biodegradation of Malachite Green in Milkfish Pond Sediments. Sustainability 2019, 11, 4179. [CrossRef]

43. Kanehisa, M.; Araki, M.; Goto, S.; Hattori, M.; Hirakawa, M.; Itoh, M.; Katayama, T.; Kawashima, S.; Okuda, S.; Tokimatsu, T.; et al. KEGG for linking genomes to life and the environment. Nucleic Acids Res. 2008, 36, D480-D484. [CrossRef] [PubMed]

44. Brown, M.N.; Briones, A.; Diana, J.; Raskin, L. Ammonia-oxidizing archaea and nitrite-oxidizing nitrospiras in the biofilter of a shrimp recirculating aquaculture system. FEMS Microbiol. Ecol. 2013, 83, 17-25. [CrossRef] [PubMed]

45. Camargo, J.A.; Alonso, A. Ecological and toxicological effects of inorganic nitrogen pollution in aquatic ecosystems: A global assessment. Environ. Int. 2006, 32, 831-849. [CrossRef]

46. Gobler, C.J.; Burkholder, J.M.; Davis, T.W.; Harke, M.J.; Johengen, T.; Stow, C.A.; Van De Waal, D.B. The dual role of nitrogen supply in controlling the growth and toxicity of cyanobacterial blooms. Harmful Algae 2016, 54, 87-97. [CrossRef] [PubMed]

47. Newell, S.E.; Davis, T.W.; Johengen, T.H.; Gossiaux, D.; Burtner, A.; Palladino, D.; McCarthy, M.J. Reduced forms of nitrogen are a driver of non-nitrogen-fixing harmful cyanobacterial blooms and toxicity in Lake Erie. Harmful Algae 2019, 81, 86-93. [CrossRef]

48. Killberg-Thoreson, L.; Baer, S.E.; Sipler, R.E.; Reay, W.G.; Roberts, Q.N.; Bronk, D.A. Seasonal Nitrogen Uptake Dynamics and Harmful Algal Blooms in the York River, Virginia. Estuar. Coast. 2020. [CrossRef]

49. He, J.; Zhang, Y.; Wu, X.; Yang, Y.; Xu, X.; Zheng, B.; Deng, W.; Shao, Z.; Lu, L.; Wang, L.; et al. A study on the relationship between metabolism of Cyanobacteria and chemical oxygen demand in Dianchi Lake, China. Water Environ. Res. 2019, 91, 1650-1660. [CrossRef]

50. Wu, Y.; Wang, F.; Xiao, X.; Liu, J.; Wu, C.; Chen, H.; Kerr, P.; Shurin, J. Seasonal changes in phosphorus competition and allelopathy of a benthic microbial assembly facilitate prevention of cyanobacterial blooms. Environ. Microbiol. 2017, 19, 2483-2494. [CrossRef]

51. Koblížek, M. Ecology of aerobic anoxygenic phototrophs in aquatic environments. FEMS Microbiol. Rev. 2015, 39, 854-870. [CrossRef]

52. Zhang, X.; Shu, M.; Wang, Y.; Fu, L.; Li, W.; Deng, B.; Liang, Q.; Shen, W. Effect of photosynthetic bacteria on water quality and microbiota in grass carp culture. World J. Microbiol. Biotechnol. 2014, 30, 2523-2531. [CrossRef]

53. Chang, B.V.; Liao, C.S.; Chang, Y.T.; Chao, W.L.; Yeh, S.L.; Kuo, D.L.; Yang, C.W. Investigation of a farm-scale multitrophic recirculating aquaculture system with the addition of Rhodovulum sulfidophilum for milkfish (Chanos chanos) coastal aquaculture. Sustainability 2019, 11, 1880. [CrossRef]

54. Qi, Z.; Zhang, X.H.; Boon, N.; Bossier, P. Probiotics in aquaculture of China-Current state, problems and prospect. Aquaculture 2009, 290, 15-21. [CrossRef]

55. Kowaltowski, A.J.; Turin, J.; Indig, G.L.; Vercesi, A.E. Mitochondrial effects of triarylmethane dyes. J. Bioenerg. Biomembr. 1999, 31, 581-590. [CrossRef] [PubMed]

56. Glanville, S.D.; Clark, A.G. Inhibition of human glutathione S-transferases by basic triphenylmethane dyes. Life Sci. 1997, 60, 1535-1544. [CrossRef]

57. Debnam, P.; Glanville, S.; Clark, A.G. Inhibition of glutathione S-transferases from rat liver by basic triphenylmethane dyes. Biochem. Pharmacol. 1993, 45, 1227-1233. [CrossRef]

58. Panandiker, A.; Fernandes, C.; Rao, K.V. The cytotoxic properties of malachite green are associated with the increased demethylase, aryl hydrocarbon hydroxylase and lipid peroxidation in primary cultures of Syrian hamster embryo cells. Cancer Lett. 1992, 67, 93-101. [CrossRef]

59. Panandiker, A.; Fernandes, C.; Rao, T.K.; Rao, K.V. Morphological transformation of Syrian hamster embryo cells in primary culture by malachite green correlates well with the evidence for formation of reactive free radicals. Cancer Lett. 1993, 74, 31-36. [CrossRef]

60. Panandiker, A.; Maru, G.B.; Rao, K.V. Dose-response effects of malachite green on free radical formation, lipid peroxidation and DNA damage in Syrian hamster embryo cells and their modulation by antioxidants. Carcinogenesis 1994, 15, 2445-2448. [CrossRef]

61. Culp, S.J.; Beland, F.A.; Heflich, R.H.; Benson, R.W.; Blankenship, L.R.; Webb, P.J.; Mellick, P.W.; Trotter, R.W.; Shelton, S.D.; Greenlees, K.J.; et al. Mutagenicity and carcinogenicity in relation to DNA adduct formation in rats fed leucomalachite green. Mutat. Res. 2002, 506-507, 55-63. [CrossRef]

62. Fox, K.R.; Higson, S.L.; Scott, J.E. Methyl green and its analogues bind selectively to AT-rich regions of native DNA. Eur. J. Histochem. 1992, 36, 263-270.

63. Müller, W.; Gautier, F. Interactions of heteroaromatic compounds with nucleic acids. A- T-specific non-intercalating DNA ligands. Eur. J. Biochem. 1975, 54, 385-394. [CrossRef] [PubMed]

64. Wolfe, A.D. Influence of cationic triphenylmethane dyes upon DNA polymerization and product hydrolysis by Escherichia coli polymerase I. Biochemistry 1977, 16, 30-33. [CrossRef] [PubMed] 